\title{
Turkish-Georgian Cooperation in the Struggle for Security in the South Caucasus (The Caucasus Stability and Cooperation Platform)
}

\section{Güney Kafkasya'da Güvenlik Mücadelesinde Türkiye-Gürcistan İşbirliği (Kafkasya İstikrar ve İşbirliği Platformu)}

\author{
Murad Asadov ${ }^{1}$ (1)
}

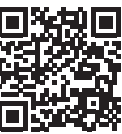

${ }^{1}$ Corresponding author/Sorumlu yazar: Murad Asadov (Independent Researcher), Baku State University, Department of Diplomacy and Integration Processes, Baku, Azerbaijan E-mail: muradasadov@bsu.edu.az ORCID: 0000-0003-1528-2533

Submitted/Bașvuru: 02.03 .2021 Accepted/Kabul: 03.08.202

Citation/Atıf: Asadov, Murad. "TurkishGeorgian Cooperation in the Struggle for Security in the South Caucasus (The Caucasus Stability and Cooperation Platform)". Avrasya incelemeleri Dergisi - Journal of Eurasian Inquiries

10, 1 (2021): 209-224

https://doi.org/10.26650/jes.2021.012

\section{ABSTRACT}

With the collapse of the Soviet Union (SU), the South Caucasus region has been in the interest of the world's great powers. The South Caucasus has been a key to maintaining peace and stability on the continent. Formation of new states in the South Caucasus and Central Asia after the collapse of the SU raised to have relations with the Turkic peoples of Central Asia first in the history of the Republic for Turkey. Foreign policy the Caucasus continues to evolve in its foreign policy strategy. Because in terms of the security of Anatolia, permanent peace and stability in the South Caucasus has a special importance for Turkey. However, there were forces that did not want lasting peace and stability in the region, generally Russia hinders Turkey's peaceful policies in the region.

This article examines Turkey's role in maintaining security in the South Caucasus, Turkey's and Russia's rivalry in the political process in the region, Turkey's role in restoring security in the region in the Russia-Georgia war, and the Caucasus Stability and Cooperation Platform and other power centers in the region, aimed at the economic, political, military and cultural interests of the challenges and their effects posed by Turkey. Also in the article have been analyzed one of the three South Caucasus states of Georgia, the conflicts in Abkhazia and South Ossetia in Georgia, within Georgia's territorial integrity. Finally, some examples are provided to ensure security in the region.

Keywords: Turkey, Russia, Georgia, South Caucasus, Caucasus Stability and Cooperation Plaform, "Common Caucasus House"

öz

Sovyetler Birliği'nin (SB) çöküşünün ardından Güney Kafkasya bölgesi dünyanın büyük güçlerinin çıkarında olmuştur. Güney Kafkasya, kıtada barış ve istikrarın korunmasının anahtarı olmuştur. SB'nin dağılmasından sonra Güney Kafkasya ve Orta Asya'da yeni devletlerin oluşması, Türkiye için Cumhuriyet tarihinde ilk kez Orta Asya Türk halkları ile ilişkiler kurmayı ve onlara sahip olmayı gündeme getirdi. Türkiye dış politika stratejisinde Güney Kafkasya, bölgesi gelişmeye devam ediyor. Çünkü Anadolu'nun güvenliği açısından Güney Kafkasya'da 
kalıcı barış ve istikrarın olması Türkiye için özel bir öneme sahiptir. Ancak bölgede kalıcı barış ve istikrarın olmamasını istemeyen güçler vardı ki, genellikle Rusya Türkiye'nin bölgedeki barışçıl politikalarına engel oluyor. Bu makale, Güney Kafkasya'da güvenliğin sağlanmasında Türkiye'nin rolünü, bölgedeki siyasi süreçte Türkiye ve Rusya'nın rekabetini, Rusya-Gürcistan savaşında bölgede güvenliğin sağlanmasında Türkiye'nin rolünü ve "Kafkas İstikrar ve İşbirliği Platformu" ve bölgedeki güç merkezlerinin ekonomik, siyasi, askeri ve kültürel çıkarlarının Türkiye için yarattığı sorunlar ve etkileri incelenmişti. Makale ayrıca, Türkiye'nin üç Güney Kafkasya devletinden biri olan Gürcistan'daki Abhazya ve Güney Osetya'daki ihtilafları Gürcistan'ın toprak bütünlüğü içinde çözme çabalarını da incelemektedir. Son olarak bölgede güvenliği sağlamak için bazı örnekler verilmiştir.

Anahtar kelimeler: Türkiye, Rusya, Gürcistan, Guney Kafkasya, Kafkasya Sabitlik ve İşbirliği Platformu, “Ortak Kafkasya Evi"

\section{GENIŞLETILMIŞ ÖZET}

SSCB'nin dağılmasından sonra Kafkasya' da özellikle güneyde siyasi bir boşluk oluşmuş ve bu boşluğu doldurmak için büyük güçler ortaya çıkmıştır. Bu dönemde Kafkasya'nın komşusu Türkiye bu boşluğu dolduramadı. Ancak Türkiye'nin bölge ile tarihi, dilsel, dinsel ve aşiret bağları onu bölgesinde karşı karşıya olduğu firsatları değerlendirmesi, küresel bir güç olma yolunda önemli adımlar atmasını sağlamıştır. Bu nedenle Türkiye, bu yeni jeopolitik ortam karşısında dış politikasını yeniden gözden geçirmek zorunda kalmıştır. Türkiye'nin bölgede aktif bir politika izleme isteği, Rusya'nın karşısına çıkmasına neden olmuştur.

Türkiye ve Rusya'nın Güney Kafkasya konusunda bazı farklılıkları var. Çıkarların örtüştüğü alanlardan biri olan Güney Kafkasya, hem enerji hem de Avrupa'nın enerji ihtiyacını karşılayacak boru hatlarının geçişi açısından her iki ülke için önemlidir. Ancak, Türkiye'nin Rusya ile yoğun ticareti ve kapsamlı enerji bağları, Moskova’nın Ankara'ya yaklaşımını kısmen yumuşattı. Güney Kafkasya'daki bazı konularda iki ülkenin çıkarları çatışıyor. Dolayısıyla bu yaklaşım, Dağlık Karabağ, Abhazya ve Güney Osetya gibi bazı uzun vadeli sınır çatışmalarından kaynaklanmaktadır. Bu çatışmalar aktif olmasa da, bu gerilimler çözülmeye yakın değil.

Modern uluslararası ilişkilerin aktif aktörlerinden biri olan Kafkasya bölgesi, özellikle Gürcistan, Türkiye Cumhuriyeti'nin dış politikasının önceliklerinden biridir. Bağımsızlığın ilk günlerinde Gürcistan Cumhuriyeti'nin dış politikasının temel amacı, Batı dünyasına entegre olmak, dünya ülkeleri ve uluslararası kuruluşlarla ikili ve çok taraflı ilişkileri genişletmekti. SSCB'nin dağılmasının ardından Güney Kafkasya'daki üç bağımsız devletten biri olan Gürcistan, bağımsızlığını ilan ettiği günden bu yana ülke içinde ve dışında komşu Türkiye'nin her zaman ilgi odağı olmuştur. Bölgede demokrasi ve güvenliğin geleceğini korumak için bölge ülkeleri arasındaki ilişkiler çok önemlidir. Bu, özellikle SB'nin çöküşünden sonra doğruydu. Ancak bölgede Türkiye'nin güvenliğini sürekli tehdit eden bir devlet var. Rusya, Türkiye'nin bölgedeki başarılı politikasının etkisini azaltmak için etki mekanizmasını değiştirerek bölgede daha fazla askeri güç kullanmayı planladı. Bu nedenle Türkiye, bölge ülkeleriyle ilişkilerini geliştirmeye ve faaliyetlerini sınırlayacak bir dış politika izlemeye çalışmıştır. Gürcü-Rus 
ilişkileri çerçevesinde resmi Moskova, ulusal çıkarlarını güvence altına almak için her yolu kullanıyor. Ayrılıkçı güçlere destek, askeri tehditlerin kullanılması ve enerji arzının askıya alınması, Rusya'nın en yaygın baskı araçları arasında yer alıyor. Mikheil Saakaşvili'nin iktidara gelmesinden bu yana Rusya ile Gürcistan arasındaki gerilim tırmandı. Gergin ilişkilerin nedenleri arasında Saakaşvili hükümetinin Batı yanlısı politikası, Rusya'nın çıkarlarına uymayan enerji projelerindeki aktif rolü, Gürcistan'ın NATO'ya tam üye olma isteği ve bu yönde atacağ cesur adımlar Rusya tarafından hoş karşılanamazdı. Kafkasya İstikrar ve İşbirliği Platformu, bölgesel güvenlikten derin endişe duyan Türkiye'nin iyi niyetli bir diplomatik hamlesidir. Türkiye bu şekilde bölgede inisiyatif almayı ve komşularıyla iyi ilişkiler geliştirmeyi hedefliyor. Ancak hem Kafkasya'nın karmaşık etnik ve siyasi yapısı hem de ABD ve Rusya'nın çatışan bölgesel jeopolitik çıkarları bölgede kalıcı bir barışın yaratılmasını zorlaştırmaktadır. Yine de bölgesindeki sorunlara çözüm bulmaya çalışan Türkiye, bu platformla bölgesel barışın sağlanmasına büyük katkı sağlayacaktır. Paktın ortaya çıkışı, Rus-Gürcü ilişkilerinin gergin olduğu ve Rusya’nın Batı medyasının özellikle ABD’nin Rusya’ya Türkiye üzerinden tepkisi olarak tanımladığı yeni bir askeri doktorayı kabul ettiği bir zamanda geldi. Bunu "tarihi bir gerçek" olarak değerlendiren Gürcistan, bu anlaşma sayesinde tüm dünyanın Avrasya'nın kesiştiği bu bölgeye daha fazla ilgi göstereceğini istiyordu.

Türkiye'nin girişimci bir genç insan gücü potansiyeline sahip bir ülke olması, Kafkasya'da yaşanan süreçlere müdahale etmesini sağlıyor. Ancak Ağustos 2008'deki Rus-Gürcü çatışması, Kafkasya bölgesinde güvenliğin ne kadar zayıf olduğunu bir kez daha gösterdi. Bölgenin geleceği için barışçıl ve güvenli bir ortam yaratmanın önemini yineledi. Ancak Batı'nın ve Türkiye’nin bölgede daha aktif ve ölçülü bir politika izlemesi, buradaki ülkeler için yeni firsatlar yaratabilir. Güney Kafkasya'da Ermenistan ile Gürcistan ve Türkiye'nin olası dostluk ve uzlaşması bu ülkelere fayda sağlayacaktır. Azerbaycan bazı engellere rağmen dostluk, kardeşlik ve işbirliğini sınır tanımadan sürdürebilir. Kafkasya'da barış Türkiye için son derece önemlidir. 


\section{Introduction}

Relations between Turkey and Georgia have developed in all areas since Georgia's independence, and a number of agreements have been signed between the two countries in various fields. Turkey recognized Georgia's independence on December 16, 1991. The Protocol on the Establishment of Diplomatic Relations was signed on May 21, 1992 and embassies were opened. Turkey already has consulates general in Batumi and Georgia in Istanbul and Trabzon.

Relations between Turkey and Georgia are strategic both bilaterally and regionally. Georgia plays a key role in terms of transporting Caspian energy resources to Turkish and Western markets, as well as transport links between Turkey and Azerbaijan, Russia and the Central Asian Republics. On the other hand, Turkey is also Georgia's largest trading partner: Turkey, Georgia and Azerbaijan continue trilateral cooperation in various fields, especially energy and transport. The Baku-Tbilisi-Ceyhan oil pipeline, the Baku-Tbilisi-Erzurum gas pipeline and the Baku-Tbilisi-Kars railway projects are concrete and important examples of this cooperation.

Turkey supports Georgia's territorial integrity and seeks to help resolve the country's internal affairs. Abkhazia and South Ossetia are two very important regions for the Georgian people. Russia won the Georgian-Russian conflict in 2008, declared and recognized these regions as independent, and concluded military agreements. Russia's military bases, established on the basis of bilateral agreements, have gained legitimacy at the regional level. Georgia has taken the situation to the international level and is trying to protect its rights, as it has no power to change the status of independent Abkhazia in the near future. The approach to the problem of South Ossetia is the same.

\section{Turkey's attempts to create security in the region after the Russian-Georgian war}

The relatively small region of the South Caucasus keeps attracting massive attention from regional and trans-regional actors. Until the mid-1990s, there was still uncertainty about the mid-term and long-term strategic objectives that stakeholders pursued in the region. The region itself, entrenched in ethno-political and territorial conflicts, did not have much to offer. However, by the mid-2000s, with expanding energy projects, it became tremendously difficult to underestimate the increasing strategic weight of the region. Within a short period, the South Caucasus became a catchphrase for observers and practitioners alike ${ }^{1}$.

Security, which is at the heart of Turkey's policy in the South Caucasus, requires the region to become a stable neighbor and is one of Turkey's foreign policy priorities. The goal was to create entity like a NATO and under the control of EU in the Caucasus. It would be easier to solve "frozen problems" through this institution. For this purpose, the idea of the "Common Caucasus House" put forward by the President of the Republic of Azerbaijan Heydar Aliyev

1 Vahram Ter-Matevosyan. Cooperation paradigms in the South Caucasus Making sense of Turkish-Georgian relations. Coopération au Sud Caucase : le cas des relations turco-géorgiennes. 04.2014. 103 https://journals. openedition.org/eac/689 
and the President of Georgia E. Shevardnadze deserves special attention. The statement of the President of Azerbaijan H. Aliyev : "The establishment of peace in Azerbaijan, the whole Caucasus region and the world is our most important wish" ${ }^{2}$ - once again attracted the world's attention to the existence of peace and stability in the Caucasus. However, the regional interests of the major powers did not allow the project to be implemented.

Changes in Turkey's foreign policy since the beginning of the millennium led to the emergence of the concept of "soft power" in 2002. As Turkish Foreign Minister A. Davutoglu showed in his book "Strategic Depth", this policy was based on the new Ottomanism ${ }^{3}$. In Turkey, the basis of this policy was the idea of "zero problems with neighbors"4. Turkey's geographical and historical ties made it necessary to react to the events around it. Davutoglu, a prominent figure in Turkey's foreign policy strategy, described Turkey's foreign policy as "based on regional integration, which is based on zero problems with neighbors, mediating conflicts and helping to resolve them peacefully" 5 .

For this purpose, in April 2002, the leaders of Turkey, Azerbaijan and Georgia signed the "Trabzon Agreement" in Trabzon ${ }^{6}$. With this agreement, an alliance of Turkey, Georgia and Azerbaijan was formed in the region, which began to worry neighboring Russia and Iran. It was no coincidence that the Iranian Foreign Minister paid an unscheduled visit to Moscow in early May 2002. The main issues discussed during the visit were the status of the Caspian Sea, regional security and the influence of Western countries in the region ${ }^{7}$. The Trabzon Declaration was on the agenda of the Turkish, Azerbaijani and Georgian media, as well as the Russian and Iranian media. Along with the security of the South Caucasus, Azerbaijan's support for Azerbaijan's position on the oil and gas pipelines passing through the three countries, along with further strengthening Armenia's isolation, also affected the interests of Russia and Iran. Touching upon the importance of the Trabzon Declaration ${ }^{8}$, President H.Aliyev noted:

"The agreement signed here" reflects the interests of all three states and brings these states closer economically. From this point of view, there is no doubt that the Trabzon summit was a success for Azerbaijan." 9

The "Caucasus Platform for Stability and Cooperation" adopted at the summit was a successful diplomatic move by Turkey, which is deeply concerned about regional security. In

2 Heydar Aliyev's light - the Silk Road. (Baku, 2001) 106

3 Davutoglu Ahmed. Strategic Depth. (Istanbul, 2016) 584

4 Алексаня Лarisa .Mgerovna. The "soft power" policy of Turkey towards Georgia. Turkey in world politics and economics Vestnik MGIMO University, 2016 2(47), 73

5 Interview of Prof. Dr. Ahmet Davutoglu, the architect of the last six years of Turkish foreign policy. Transverse and Longitudinal Program.TRT 31 January 2009

6 Hasanov Ali. Modern international relations and foreign policy of Azerbaijan. (Baku 2005), 698

7 The interests of Russia and Iran coincide somewhere. Gas. Kommersant, 2002, May 4

8 Arikhov J. Azerbaijan-Georgia: dynamics of development of friendly relations (1992-2003). (Baku .: Qanun, 2008), 36-37

9 The Trabzon summit called for stability in the South Caucasus. Voice newspaper, May 3 
this way, Turkey intended to take the initiative in the region, as well as to develop favorable relations with its neighbors. However, both the complex ethnic and political structure of the South Caucasus and the regional geopolitical interests of the United States and Russia made it difficult to establish lasting peace and stability in the region. Nevertheless, the importance of Turkey in seeking solutions to the problems in its region and in establishing regional peace with this platform is undeniable. The Stability Pact in the South Caucasus was first proposed by the President of the Republic of Azerbaijan Heydar Aliyev in December 1999 at the Istanbul Summit of $\operatorname{OSCE}^{10}$.

This Security Pact, which was to be established on the initiative of Heydar Aliyev, was to be included in the United States along with the Caucasus states and Turkey. This Pact was to be based on the 3+3+2 model (Azerbaijan, Georgia, Armenia + Russia, Turkey, Iran + USA and EU ${ }^{11}$. However, Azerbaijan's proposal was not welcomed in Russia, Armenia and Iran. Thus, Russia, which considers the interference of the United States, a state outside the region, in the processes in the region unacceptable, did not unequivocally accept Iran's exclusion in the formation of the regional security system ${ }^{12}$. The reason was Turkey's participation in the project with the United States and, as a result, the weakening of Russia's position in the South Caucasus. Therefore, the Russian-Iranian-Armenian triangle was placed against the USTurkey-Azerbaijan-Georgia alliance that could be formed in the South Caucasus. During a visit to Tbilisi in January 2000, Turkish President S. Demirel called for the reduction of Russian troops and the creation of a platform similar to the Southeast European Security Pact in the Balkans, primarily to restore peace in the region. At the suggestion of S. Demirel, he hoped that thanks to this pact, he would be ahead of the countries that wanted to establish their influence over the countries of the region, thus helping to maintain peace and security in the region ${ }^{13}$.

At a joint press conference with Georgian President Eduard Shvardnadze, Turkish President S. Demirel said the platform was not under the control of one country and would be an important tool in resolving ethnic conflicts in the region. Noting that the friendship and cooperation between Turkey and Georgia "has reached an unprecedented level, S. Demirel praised the inter-delegation and bilateral talks ${ }^{14}$. In fact, Turkey was trying to create for itself a secure trade corridor through the South Caucasus to Central Asia. For this, first of all, security had to be ensured in the South Caucasus region.

President of Azerbaijan Heydar Aliyev, who joined the "Silk Road in the XXI Century" conference on security in the South Caucasus via satellite on September 21, 2002 in New Haven, Connecticut, stressed the need to restore peace and security in the Caucasus. Touching upon

10 Hüseynova İrada. Heydar Aliyev and the peace process in the South Caucasus. (Baku .: Çaşığlu Publishing House, 2008) 454

11 Mammadov Novruz. Foreign policy: realities and vision of the future, (Baku 2013) .25

12 Hasanov Ali. Modern international relations and foreign policy of Azerbaijan. (Baku 2005,) 700

13 Serkan Demirtaş. A new Caucasus reference, Cumhuriyet newspaper, January 17, 2000

14 Demirel: He wanted the Caucasus Pact. https://www.evrensel.net/haber/119795/ demirel-kafkas-istikrar-paktiistedi 2000, 15 January (Erişim tarihi: 13.02.2020) 
the conflicts in Georgia, the President of Azerbaijan said he supported their settlement within the framework of the territorial integrity of the Georgian state. The Azerbaijani government described the conflicts in Georgia as an internal affair of the country. The conference emphasized that the passage of the BTC main export pipeline through Georgia is important for peace and stability in the region and in the region in general ${ }^{15}$.

In particular, Michael Cecire argues that Turkey "is visibly ascendant as a Caucasus power" and "Turkey's Caucasus system" already functions in the region, where Turkey is perceived as a "merchant hegemon". Moreover, in his opinion, Turkey-Azerbaijan-Georgia trilateral cooperation has been a challenge to the common perception of the region being under the Russian dominance ${ }^{16}$. Asbed Kotchikian ascertain, Georgia, first and foremost, provides the most direct and stable land route from Turkey to Azerbaijan and Central Asia, therefore, its role is indispensable and profound. Moreover, Georgia's engagement in Caspian energy projects as a transit country and Turkey's investments in the Georgian economy have made the two countries irreversibly interdependent ${ }^{17}$.

The "Stability Pact for the Caucasus" prepared under the leadership of political scientist M. Emerson was to resolve the conflict in the region. According to M. Emerson.

"The EU, which has not been very effective in the Caucasus, has developed proposals to end ethnic conflicts in the region and achieve economic development in the region." 18

However, a number of intra-regional issues were needed to implement this pact.

Stating that Turkey supports Georgia's territorial integrity, inviolability of borders, stability, sovereignty and political integrity, Turkish President Demirel said he considered it an important condition for peace and stability in the region. The emergence of such an idea was described by the media as a response of the United States to Russia through Turkey at a time when Russian-Georgian relations were strained and Russia adopted a new military declaration. Evaluating this as a "historical fact", Georgian President Eduard Shvarnadze said that due to this pact, attention will be paid to the region where Eurasia intersects.

During Turkish President Ahmet Sezer's visit to Tbilisi on November 8, 2001, the pact was renegotiated and it was stressed that the implementation of the pact would be very beneficial for peace and security in the region ${ }^{19}$. As the realization of this pact is a threat to upset the balance of power in the South Caucasus, Russia has tried to prevent it by all means, so the realization of the pact is still a dream. There was no doubt that the implementation of the South Caucasus Security Pact would weaken Russia's influence in the region, increase Turkey's influence in

15 Heydar Aliyev. Our independence is eternal. (Book 40 (June, 2002 - August, 2002). B .: Azerneshr, 2012) 109

16 Cecire Michael Hikari, “The Merchant Hegemon: Georgia's Role in Turkey's Caucasus System”, (n Kornely Kakachia and Michael Cecire (eds.), 2013), 111

17 Kotchikian Asbed, The Perceived Roles of Russia and Turkey in Georgian Foreign Policy, (Insight Turkey, vol. 6, no. 2, 2004), 43.

18 Binay Mehmed. After the Balkans, the Caucasus established a pact. arsiv.ntv.com.tr/news/ 5088.asp 19 May 2000

19 Ministry of Foreign Affairs Press Statement January 8, 2001, www.mfa.gov.tr 
the region, as well as expand the opportunities for Western countries to interfere in regional politics and security ${ }^{20}$. Georgian President Eduard Shvardnadze went further and said he wanted Turkish troops to be stationed instead of Russian troops to be withdrawn from Abkhazia ${ }^{21}$.

Georgia, which seeks to maintain its territorial integrity by developing ties with the United States and NATO, has also pursued a policy of integration into the Western world.However, Saakashvili, who failed to get the support he hoped for from the West in the US-led operation in South Ossetia, was defeated by Russia and Georgia's territorial integrity was clearly violated. The Washington Post did not respond to a question:

"If Saakashvili is not with us, with whom is the West?" In connection with this incident, Georgia condemned the policy of the United States and the European Union against Russia, and tried to save its country from the difficult situation in which it found itself. " 22

However, it failed to do so because the United States was playing a "double game" in its policy. He did not want to spoil relations with a state like Russia. Clearly, Georgia is one of the regions facing Moscow and Ankara. After the events of August 2008, Russia recognized South Ossetia and Abkhazia as independent states. However, Turkey supports the sovereignty and territorial integrity of Georgia and wanted a peaceful settlement of the conflict within the framework of international law. Unlike Moscow, Ankara also supported the EU's Eastern Partnership policy, which aims to strengthen economic and social integration between the South Caucasus republics. It should also be noted that Turkey's approach to the South Caucasus was welcomed by Moscow. That is why, after the Russia-Georgia conflict in August 2008, Ankara began to show a political course that did not accept the interference of foreign players in regional issues. It is no coincidence that in 2008 Turkey revived the line of strengthening regional dialogue within the framework of the Caucasus Stability and Cooperation Platform ${ }^{23}$.

Although Russia and Turkey have different and often contradictory goals in the region, increased cooperation may create an opportunity to prevent the escalation of conflicts in the region.

-Ankara can use its ties with NATO and Russia to prevent an incident that may pose a security risk in the South Caucasus. While both Russia and NATO conduct military exercises by increasing their presence in the South Caucasus, the low flight of Russian jets or the interception of NATO planes increased the risk of accidents. Dialogue at all levels is essential and Turkey can introduce additional communication channels.

-Resolving the Nagorno-Karabakh conflict could prevent Moscow and Ankara from escalating again. Turkey and Russia should come to an agreement in the region by emphasizing

20 Zalmay Khalilzad, Ian Lesser and Stephen Larrabee, The Future of Turkish-Western Relations: Toward a Strategic Plan, (Santa Monica, CA, RAND, 2000), 39

21 Turkey in external press, RFE / RL Newsline, June 13, 2001 https://www.rferl.org

22 Çoğal Necat. References in the Caucasus. 09.06.2015 http://nejatcogal.com/ 2015/06/09/1723

23 Mamduh Karakullukçu and Dmitri Trenin. Examining Opportunities for Russian-Turkish Cooperation in a Challenging Region. (Turkey, 2014) 16 
the economic benefits of both states to have a lasting peace in this region, which is of vital importance for transit between Asia and Europe, and the Middle East and Russia.

\section{The importance of the "Caucasus Stability and Cooperation Platform" for regional security}

During the Russian-Georgian conflict, Turkey launched the "Caucasus Stability and Cooperation Platform" to restore peace and stability in the South Caucasus. However, this idea was welcomed by the United States and Russia, but was not resolved, because Russia agreed to the pact on the condition that there would be no threat to its interests. Armenian President Robert Kocharyan said that the pact would be effective if all countries in the region were included, and Georgian Foreign Minister Menagrashvili would fully support the project. Later, this project was brought up again during the visit of Turkish Prime Minister Recep Tayyip Erdogan to Moscow. During the talks with Russian President Dmitry Medvedev and Prime Minister Vladimir Putin, the Caucasus Union project was the main topic of discussion, as a result of which it was decided to implement the "Caucasus Platform for Stability and Cooperation." ${ }^{24}$

On August 13, 2008, the parties agreed to establish a pact of peace, security and stability in the Caucasus, headquartered in Baku. The importance of establishing the Caucasus Platform for Stability and Cooperation was stated as follows:

"First of all, this platform should be geographically based, aim for peace and security in the region, and focus on economic cooperation and energy security" 25.

During his visit to Tbilisi, Erdogan also held talks with Georgian President Mikheil Saakashvili on the same topic. The main goal of the implementation of this pact was that the "Caucasian Five" Azerbaijan, Georgia, Armenia, Russia and Turkey should act as a guarantor of the settlement of problems within the region ${ }^{26}$.

However, the five-day Russia-Georgia war and the events in Ukraine led to a completely new geopolitical situation in the South Caucasus, and Turkey's regional policy became more cautious. A temporary ceasefire has been reached with "six articles" proposed by French President Nicolas Sarkozy, who is visiting Moscow and Tbilisi on behalf of the EU to resolve the conflict. Although Russia ended its military operations, threats to isolate Russia from the global system and the Western world as a result of US intervention, the Kremlin's comments that "Georgia's territorial integrity cannot be mentioned" indicate that tensions in the South Caucasus will continue.

24 Alliance in 24 hours August 15, 2008.http: //web.archive.org/web/20080819153520/http://www.stargazete. com:80/politika/24-saatte-ittifak-120867.htm (Erişim tarihi: 14.09.2018)

25 Aliyev's support for cooperation in the Caucasus. 20.08.2008 http://www.radikal.com.tr/dunya/kafkasyaisbirligine-aliyev-destegi-894659/

26 Safrançuk İvan, Kazarov Püstəm. The Caucasus after the 2008 crisis is a new reality, new opportunities, limited results. The role of Russia and Turkey in the security system of the South Caucasus. (SAM. Bak1. 2012.) 39 
The war significantly delayed negotiations on the Caucasus Pact, but the foreign ministers of the five countries met again within the framework of the OSCE summit in Helsinki in December 2008. The Turkish Foreign Minister said that the summit was positive and that "discussions were held on the goals, principles and mechanisms of the platform."27. However, the continuation of Armenia's aggressive policy hindered the successful implementation of the platform. Turkey's efforts to strengthen its position in the region were particularly irritating to Iran. Turkey, under pressure from the United States and Russia, signed the "Protocol on the Establishment of Diplomatic Relations" and the "Protocol on the Development of Bilateral Relations" with Armenia on October 10, 2009 in Zurich. Nevertheless, Armenia's continued policy of aggression against Azerbaijan led Turkey to refuse. ${ }^{28}$ According to Hasanli, one of the Azerbaijani authors:

"The South Caucasus is of unprecedented importance in Turkey's foreign policy, not only because of its historical connection, but also because of the requirements of modern times. Turkey has a greater right to gain influence in a region where geopolitical interests collide " 29.

The Georgian leadership understood that Moscow would defend its position in the region by all means, but did not expect that the situation would develop before the war. The wrong steps taken by Saakashvili before the August war were an opportunity for Moscow. Although Russia was able to strengthen its position in the region at the end of the five-day war, it had a significant negative impact on Moscow's image in the eyes of the world community ${ }^{30}$.

Under the circumstances, the former Turkish Foreign Minister said that the I. Turkmen Caucasus platform was "far from being close to reality." ${ }^{31}$ According to Turkmen, the realization of this pact cannot be discussed in the context of the conflict between Azerbaijan and Armenia and the closure of the border with Turkey. According to Turkish author Hakan Aksay: "If Turkey wants to pursue an effective policy in the Caucasus, it must have good relations with all countries, including Armenia." ${ }^{32}$. Another author, Ismet Berkan, wrote: "Even if there are regional states in this pact, it will not be of any use, because it is impossible for five states to sit at the same table and eat" 33 . N. Ozcan, one of the TOBB politicians, wrote that this plan implemented under the leadership of Turkey was impossible: "Caucasian states and Turkey do not want to see issues between themselves, strong Turkey can change all issues in the region" 34 .

27 Barış Taslağı Üzərinde Çalışılabilir. Cümhuriyyət qəzeti. 5 yanvar 2008

28 Turkish-Armenian political relations. The official website of the Turkish Ministry of Foreign Affairs is http: // www. mfa.gov.tr/turkiye-ermenistan-siyasi-iliskileri.tr.mfa (Erişim tarihi; 11.12.2014)

29 Hassall Jamil. New geopolitical situation in the Chernomorsk-Caspian region after August 2008. Black SeaCaspian: search for new formats of security and cooperation. (Moscow, 2011) 12

30 Andrew Purvis, Who Started the War in Georgia ?, Time, September 3, 2008, http://www.time.com/time/world/ article/0,8599,1838305,00.html

31 İltər Turkmen. The New Geopolitical Picture in the Caucasus. Hürriyət qəzeti.16 avqust 2008 http://www. hurriyet.com.tr/arsiv

32 Hakan Aksay. Ankara and Caucasus policy. Taraf Gaz., August 16, 2008 http: // taraf.com. tr / arsiv

33 Ismet Berkan. Caucasus Platform. Radikal newspaper, August 21, 2008 http: // www. radikal.com.tr

34 Imanov Vugar. Caucasus Stability and Cooperation Platform. Central Eurasian Studies: Past, Present and Future.(Editors: Komatsu Hisaa, Karasar Shahin, Dadayev Timur, Guljanat Kurmangaliyeva Ercilasun. Maltepe University), No 46 2011/5, 147 
Russia's and the West's positions on Turkey's strengthening in the South Caucasus coincided, as Russia and the West saw Turkey's strengthening in the Caucasus as a Turkish-Muslim threat. The situation forced Turkey to be sensitive and cautious in its policy in the South Caucasus.

Russia has said it respects Georgia's territorial integrity and has said it wants a diplomatic solution. By violently violating the norms of international law by using force against an independent country without the consent of the United Nations, he signed a resolution violating the territorial integrity of an independent state for the first time since the collapse of the Soviet Union. The situation can be attributed to the West's recognition of Kosovo's independence. On September 2, Russian Foreign Minister Sergei Lavrov met again with Turkish Foreign Minister Babacan to discuss the Caucasus Platform. Russia's ambassador to Ankara V. Ivanov said at a press conference on August 27 that the platform would be discussed at the BSEC summit ${ }^{35}$. Armenian Foreign Minister Eduard Nalbadyan said that his country was always ready to discuss issues of regional cooperation and security. The head of the Caucasus Institute, Alexander Iskandaryan, wrote about the platform: "He noted that this platform is not a real political program and is a tool in the hands of Turkey to enter the South Caucasus region"36.

Martirosyan described the project as a "Turkish attack on the Caucasus." ${ }^{37}$. Turkey has used all the power of regional diplomacy to prevent the project from failing. If it happens, Turkey could achieve greater success not only between Russia and Georgia, but also between Russia and the West. Later, this factor would play an important role in Turkish-Russian rapprochement.

The election of Giorgi Margvelashvili as President of Georgia on November 17, 2013 resulted in a number of changes in the country's foreign policy. G. Margvalashvili said in an interview to the press:

"Permanent peace, interstate solidarity and cooperation must prevail in the Caucasus region. I saw that we agree with Turkey on this issue, and I can say that in addition to preserving our rich traditions and identity, we also agree on building modern countries and developing our future. Our dream is to create a Caucasian model of successful and lasting solidarity with the modern world" 38

The establishment of the High-Level Strategic Cooperation Council (HSCC) is important for the further development of relations between Turkey and Georgia. The first meeting of the CCTS was held on July 19, 2016 in Ankara. This body, which includes Azerbaijan, is an important step in restoring peace and stability in the region ${ }^{39}$. Turkey's foreign policy has recently become more related to the Middle East, so the policy of the South Caucasus has

35 Imanov Vugar. Caucasus Stability and Cooperation Platform. 148

36 Imanov Vugar. Caucasus Stability and Cooperation Platform. 150

37 Martirosyan S. Turkish throw in the Caucasus. September 10, 2008 http: // www. warandpeace.ru/ru/analysis/ view/27214

38 Prezident of Georgia Giorgi Margvelashvili: Turkey is a strategic partner of Georgia. Special reportage. Ekovitrin's Journal. Dekabr 2014

39 Turkish-Georgian political relations. www.mfa.gov.tr 
faded into the background. However, the statement signed in Trabzon with the participation of the Foreign Ministers of Azerbaijan and Georgia showed that this process continued silently ${ }^{40}$.

The Second Nagorno-Karabakh War between Armenia and Azerbaijan ended on November 10, 2020 with the former acknowledging defeat. Various factors explain Azerbaijan's military victory, with two considered by observers as "magic bullets": the role of unmanned aerial vehicles sourced from Turkey and Israel, and the advisory role of Turkish senior military personnel in Azerbaijan's operational plans and command. But, while exceedingly important, these factors do not sufficiently explain the outcome of the conflict. There is an additional significant factor ${ }^{41}$. Soon after the dissolution of the Soviet Union, Turkey began building Azerbaijan's armed forces, along with those several other former Soviet republics. Azerbaijan's recent victory against Armenia was the result of this thirty-year effort.

The recent exchange of gunfire lasted for three days in mid-July, along the northern border between Armenia and Azerbaijan. The incident included artillery, tank fire and drone involvement, causing military casualties, as well as affecting villages on both sides of the border. Such incidents are not uncommon. The roots of this conflict stem back to the breakup of the Soviet Union and the establishment of independent states and to the controversy over the Nagorno-Karabakh region. The war lasted four years, in which Russia actively aided Armenia in gaining control. Despite international recognition of Azerbaijan's territorial integrity, including through UN Security Council decisions during the war itself, on the ground Armenia continues to de facto control the region to this day, including occupied territories outside Nagorno-Karabakh, with active military, political and economic support from Russia ${ }^{42}$.

By siding with Azerbaijan in the conflict over Nagorno-Karabakh, Turkey is primarily pursuing the goal of undermining the current status quo of the region. Ankara aims above all to secure a place at the table where a solution to the conflict between Armenia and Azerbaijan will be negotiated in the future. The Syrian scenario should serve as an example. Turkey thus wants to negotiate with Russia in the South Caucasus, preferably without Western actors. Ankara's plans are not uninteresting for Moscow. However, because of the complexity of Turkish-Armenian relations, there is a risk that Armenia and Turkey might become the eventual opponents in this conflict, rather than Armenia and Azerbaijan. The EU's engagement should not be determined by its tense relationship with Turkey, but rather by the UN Security Council resolutions on Nagorno-Karabakh ${ }^{43}$

40 Tüysüzoğlu Göytürk. Turkey, South Caucasus and Trabzon notification, June 2012 /http://politikaakademisi. org/2012/06/11/turkiye-guney-kafkasya-ve-trabzon-bildirisi

41 Halduk Yalçınkaya, "Turkey's Overlooked Role in the Second Nagorno Karabahk War. 21.01.2021 The German Marshall Fund of the United Stade". www.gmfus.org/news/turkeys-overlooked-role-second-nagorno-kabakh-war

42 Avinoam Idan, Russia and Turkey: Behind the Armenia-Azerbaijan Clashes? Published in Analytical Articles August 31, 2020, the CACI Analyst http://cacianalyst.org/publications/analytical-articles/item/13636-russiaand-turkey-behind-the-armenia-azerbaijan-clashes?.html (Erişim tarihi: 14.09.2021)

43 Daria Isachenko, Turkey-Russia Partnership in the War over Nagorno-Karabakh. SWP Comment 2020/C 53, 19.11.2020, https://www.swp-berlin.org/10.18449/2020C53/ (Erişim tarihi: 13.06.2021) 
The violence in the region of Tovuz is, it seems, in actuality reflects a clash between Russia and Turkey, wherein Russia used Armenia as leverage in its confrontation with Turkey. It would seem that the Russian initiative was meant to be a message to Turkey vis-à-vis the energy export infrastructure crossing the Caucasus to At the time of the incident itself, the Russian news agency TASS quoted a source from Gazprom Armenia, a subsidiary of Russia's Gazprom, reporting that some of their pipelines had been damaged during the incident. That was enough to justify Russia's involvement, and Russian foreign Minister Lavrov met with representatives of both sides. The following day, Turkish President Recep Tayyip Erdogan pledged that that Turkey would support Azerbaijan in its conflict with Armenia. Turkey's staunch support of Baku was aimed, this time, not only at Armenia, but at Moscow, inviting a response, and a response there was. Presidents Putin and Erdogan had a telephone conversation ten days after the event to discuss the escalation of the situation along the Armenia-Azerbaijan border. Putin expressed his willingness to coordinate efforts to bring about stability in the area, and the two presidents opened a direct dialogue, beyond the scope of Armenia and Azerbaijan, centered on stability in the Caucasus, opening the door to broader issues ${ }^{44}$. 'It's time to pay.' With these words, Turkish President Recep Tayyip Erdoğan backed Azerbaijan's demand to Armenia to vacate the Azerbaijani territories occupied by Armenian troops as well as Nagorno-Karabakh, immediately after the start of the military escalation on September 27, 2020. Later, Erdoğan vehemently criticised the USA, France and Russia who as co-chairs of the OSCE Minsk Group mediate in the conflict. From the perspective of Azerbaijan and Turkey, this format is neither neutral nor efficient, as no solution has been found for nearly thirty years ${ }^{45}$. Turkey is explicitly on Azerbaijan's side and is prepared to give Baku full support 'both on the field and at the negotiating table'. At the same time, it has repeatedly stressed its interest in resolving this conflict together with Russia.

After the Azerbaijan-Armenian war Ankara became Baku's closest ally can be attributed in large part to the efforts of Azerbaijan. The often-quoted statement in Turkey in reference to Azerbaijan, 'one nation, two states', was coined by former Azerbaijani President Heydar Aliyev in the 1990s. After its separation from the Soviet Union, Azerbaijan could count on Turkey's support not only in integration into international organisations, but also in the establishment of its own armed forces after the first war over Nagorno Karabakh. The legal framework for Turkey's involvement in the current conflict is provided by the Strategic Partnership and Mutual Assistance Agreement concluded by Ankara and Baku in 2010. In addition to joint military exercises, the treaty stipulates that the signatories will help each other 'by all possible means' in the event of 'aggression' by a third party. The impetus for the deepening of cooperation

44 Avinoam Idan, Russia and Turkey: Behind the Armenia-Azerbaijan Clashes? Published in Analytical Articles August 31, 2020, the CACI Analyst http://cacianalyst.org/publications/analytical-articles/item/13636-russiaand-turkey-behind-the-armenia-azerbaijan-clashes?.html (Erişim tarihi: 14.09.2021)

45 Daria Isachenko, Turkey-Russia Partnership in the War over Nagorno-Karabakh. SWP Comment 2020/C 53, 19.11.2020, https://www.swp-berlin.org/10.18449/2020C53/ (Erişim tarihi: 13.06.2021) 
between Ankara and Baku in the military field was provided by similar agreements between Russia and Armenia. Already in 2010, the conclusion of the partnership agreement between Ankara and Baku was seen as a sign of Azerbaijan's dissatisfaction with the Minsk Group.

In general, the Caucasus Platform for Stability and Cooperation is a positive diplomatic move by Turkey, which is deeply concerned about regional security. This is an indication of Turkey's intention to take the initiative in the region and to develop good relations with its neighbors. However, both the complex ethnic and political structure of the South Caucasus and the conflicting regional geopolitical interests of the United States and Russia make it difficult to create an environment of lasting stability in the region. Nevertheless, by implementing this platform, Turkey tried to show that hopes for peace in the Caucasus have not been completely extinguished. There are still a number of forces hindering the realization of this platform for peace in the South Caucasus region, which is part of Turkey's eastern security.

\section{Conclusion}

Moscow shows once again that it can gather power by triggering conflicts and conflicts. Will Western capitals in Georgia, Ukraine and the Caucasus, which have been disabled, will again swallow Russia's policy of filling power gaps? We will see what the effect of the Armenian lobby will be in the USA going to the presidential elections. That's clear. A geopolitical vacuum was created, stretching from Libya to the Eastern Mediterranean, Syria, and the Caucasus. Our post-COVID-19 world is gradually drifting into post-World War I uncertainty and power struggle. The partial withdrawal of the USA and the inability of the EU to formulate foreign policy facilitate Russia's moves to fill new power gaps. While Turkey's relations with Azerbaijan and Georgia are expanding, relations with Armenia, another country in the region, remain tense. Russia, Turkey's rival in the region, has historically been reluctant to withdraw from the Caucasus. Even in his foreign policy doctrine of "close circle", he attached great importance to the region and did not intend to become an important actor in the region.

Turkey, a country with strong geopolitical potential, allowed it to interfere in the processes in the South Caucasus. However, the events of 44-day war between Azerbaijan and Armenia showed how weak security is in the Caucasus region. It reiterated the importance of ensuring peace and a secure environment for the future of the region. Like the countries of the South Caucasus, the possible friendship and reconciliation between Armenia and Georgia and Turkey will benefit these countries. It is possible to continue such relations with Azerbaijan without borders. Peace in the Caucasus is extremely important for Turkey. Western capitals criticizing Ankara's rapprochement with Moscow should see that Turkey partially balances Russia in the South Caucasus. On the other hand, it is time for Turkey to look at these geopolitical realities of the West not with ideological glasses, but with the rationality of strategic interests. 
Peer-review: Externally peer-reviewed.

Conflict of Interest: The author has no conflict of interest to declare.

Grant Support: The author declared that this study has received no financial support.

Hakem Değerlendirmesi: Dış bağımsız.

Çıkar Çatışması: Yazar çıkar çatışması bildirmemiştir.

Finansal Destek: Yazar bu çalışma için finansal destek almadığını beyan etmiş̧ir.

\section{References/Kaynakça}

Avinoam Idan, "Russia and Turkey: Behind the Armenia-Azerbaijan Clashes?" Published in the CACI Analytical August 31, 2020, Analyst Erişim 14 Eylül 2021 http://cacianalyst.org/publications/analytical-articles/ item/13636-russia-and-turkey-behind-the-armenia-azerbaijan-clashes?.html

Arikhov J. Azerbaijan-Georgia: dynamics of development of friendly relations (1992-2003). Baku .: Qanun, 2008

Алексаня Лarisa .Mgerovna. The "soft power" policy of Turkey towards Georgia. Turkey in world politics and economics. Vestnik MGIMO University 2016 2(47) 71-83

Andrew Purvis, Who Started the War in Georgia ?, Time, September 3, 2008, Erişim 09 Eylül 2020 http:// www.time.com/time/world/article/0,8599,1838305,00.html

Alliance in 24 hours August 15, 2008. http: //web.archive.org/web/20080819153520/http://www.stargazete. com:80/politika/24-saatte-ittifak-120867.htm

Aliyev's support for cooperation in the Caucasus. 20.08.2008 http://www.radikal.com.tr/dunya/kafkasyaisbirligine-aliyev-destegi-894659/

Binay Mehmed. After the Balkans, the Caucasus established a pact. 19 May 2000 Erişim 25 Ağustos 2020 arsiv.ntv.com.tr/news/ 5088.asp

A belt-a-road-project extending into the future. Official Gazette, January 27, 2017

Cecire Michael Hikari, “The Merchant Hegemon: Georgia's Role in Turkey's Caucasus System”, in Kornely Kakachia and Michael Cecire (eds.), 2013

Çoğal Necat. References in the Caucasus. 09.06.2015 Erişim 11 Ocak 2020 http://nejatcogal.com/2015/06/09/1723

Davutoglu Ahmed. Strategic Depth. Istanbul, 2016

Demirel: He wanted the Caucasus Pact., 15 January Erişim 13 Şubat 2020 https://www.evrensel.net/haber/119795/ demirel-kafkas-istikrar-pakti-istedi

Daria Isachenko, Turkey-Russia Partnership in the War over Nagorno-Karabakh. SWP Comment 2020/C 53, 19.11.2020, Erişim 13 Haziran 2021 https://www.swp-berlin.org/10.18449/2020C53/

Ministry of Foreign Affairs Press Description January 8, 2001, Erişim 06 Şubat 2020 www.mfa.gov.tr

Hakan Aksay. Ankara and Caucasus policy. Taraf Gaz., August 16, 2008 Erişim tarihi: 07 Kasım 2020 http: // taraf.com. tr / arsiv

Haldun Yalçınkaya, "Turkey's Overlooked Role in the Second Nagorno Karabahk War. 21.01.2021 The German Marshall Fund of the United Stade”. January 21, 2021 Erişim 06 Şubat 2021 www.gmfus.org/ news/turkeys-overlooked-role-second-nagorno-kabakh-war

Heydar Aliyev. Our independence is eternal. Book 40 (June, 2002 - August, 2002). B .: Azerneshr, 2012

Heydar Aliyev's light - the Silk Road. Baku, 2001 
Hasanov Ali. Modern international relations and foreign policy of Azerbaijan. Baku 2005.

Hasanli Jamil. New geopolitical situation in the Chernomorsk-Caspian region after August 2008. Black SeaCaspian: search for new formats of security and cooperation. Moscow. 2011

Huseynova Hicran. Azerbaijan in the system of European integration processes. Baku 2008

Hüseynova İrada. Heydar Aliyev and the peace process in the South Caucasus. Baku: Çaşığlu Publishing House, 2008

Ismet Berkan. Caucasus Platform. Radikal newspaper, August 21, 2008 Erişim 12 Mart 2020 http: // www. radikal.com.tr/

Imanov Vugar. Caucasus Stability and Cooperation Platform. Central Eurasian Studies: Past, Present and Future. Editors: Komatsu Hisaa, Karasar Shahin, Dadayev Timur, Guljanat Kurmangaliyeva Ercilasun. Maltepe University, No 46 2011/5,

Interview of Prof. Dr. Ahmet Davutoglu, the architect of the last six years of Turkish foreign policy. Transverse and Longitudinal Program.TRT 31 January 2009 Erişim 06 Ocak 2018

Martirosyan S. Turkish throw in the Caucasus. September 10, 2008 Erişim 06 Ocak 2020 http: // www. Warandpeace.ru/ru/analysis/view/27214/

Mammadov Novruz. Foreign policy: realities and vision of the future, Baku 2013

Mamduh Karakullukçu and Dmitri Trenin. Examining Opportunities for Russian-Turkish Cooperation in a Challenging Region. Turkey, 2014

Kotchikian Asbed, "The Perceived Roles of Russia and Turkey in Georgian Foreign Policy", Insight Turkey, vol. 6 , no. 2 , 2004, p. 33-44.

Serkan Demirtaş. A new Caucasus reference, Cumhuriyet newspaper, January 17, 2000

Safrançuk İvan, Kazarov Püstəm. The Caucasus after the 2008 crisis is a new reality, new opportunities, limited results. The role of Russia and Turkey in the security system of the South Caucasus. SAM. Bak1. 2012.

The interests of Russia and Iran coincide somewhere. Gas. Kommersant, 2002, May 4

Turkish-Georgian political relations. Erişim 12 Aralık 2019 www.mfa.gov.tr

Tüysüzoğlu Göytürk. Turkey, South Caucasus and Trabzon notification, June 2012 Erişim 09 Şubat 2020 / http://politikaakademisi.org/2012/06/11/turkiye-guney-kafkasya-ve-trabzon-bildirisi/

The Trabzon summit called for stability in the South Caucasus. Voice newspaper, May 3

Turkish-Armenian political relations. The official website of the Turkish Ministry of Foreign Affairs. Erişim 12 Mart 2020 http: // www. mfa.gov.tr/turkiye-ermenistan-siyasi-iliskileri.tr.mfa

Turkey in external press, RFE / RL Newsline, June 13, 2001 Erişim 06 Şubat 2020 https://www.rferl.org

Workable on the Peace Draft. Cumhuriyet newspaper, January 5, 2008

Vahram Ter-Matevosyan. Cooperation paradigms in the South Caucasus Making sense of Turkish-Georgian relations. Coopération au Sud Caucase: le cas des relations turco-géorgiennes. 04.2014. https://journals. openedition.org/eac/689

Zalmay Khalilzad, Ian Lesser and Stephen Larrabee, The Future of Turkish-Western Relations: Toward a Strategic Plan, Santa Monica, CA, RAND, 2000, 